J. Clin. Chem. Clin. Biochem.

Vol. 15, 1977, pp. 549-551

\title{
Influence of Drugs on Clinical Chemical Data for Serum Glucose, Investigated with the Automated Glucose Oxidase-Perid Method
}

\author{
By Mira Keler-Bačoka and Andrina Stojanovski-Bubanj \\ Institute of Medical Biochemistry, Clinic for Internal Diseases, Medical Faculty, University of Zagreb, \\ Zagreb, Rebro, Yugoslavia
}

(Received December 13, 1976/April 7, 1977)

\begin{abstract}
Summary: Fifty drugs, applied in the therapy of internal diseases, were investigated for their effect on the clinical chemical determination of serum glucose by the automated GOD-Perid method. The results showed a statistically significant depression of the reported glucose value, by 7 drugs containing the pyrazolone group and its derivates (Baralgin, Butazolidine, Analgin, Novalgetol, Analgocain, Irgapyrin, Aminopyrin) $P<0.001 ; P<0.01$. The influence depends on the quantity of drug and on the time interval between loăding and glucose analysis.
\end{abstract}

\section{Einfluß von Arzneimitteln auf klinisch-chemische Serumglucose-Ergebnisse, untersucht mit der automatisierten GOD-Perid Methode}

Zusammenfassung: Es wurde der Einfluß von 50 Arzneimitteln, welche in der Therapie innerer Krankheiten Anwendung finden, auf klinisch-chemische Ergebnisse für Serumglucose, erhalten mit der automatisierten GOD-Perid Methode, geprüft. Die Ergebnisse zeigen einen statistisch signifikanten $(P<0,001 ; P<0,01)$ erniedrigenden Einfluß von 7 Arzneimitteln, welche die Pyrazolongruppe und deren Derivate enthalten (Baralgin, Butazolidin, Analgin, Novalgetol, Analgocain, Irgapyrin, Aminopyrin) auf die Glucosewerte. Der Einfluß ist von der Arzneimittelmenge sowie vom Zeitintervall zwischen Applikation und Glucoseanalyse abhängig.

\section{Introduction}

Clinical chemical data for blood glucose, determined with specific glucose-oxidase reactions, are influenced by ascorbic acid $(1,2)$, hydrogen-peroxide and hypochlorite (3), diuretics and some other drugs (4). The interference of the sulphonylurea drugs, Tolazamide and Tolbutamide, in the determination of glucose by the GOD-Perid method has been described $(5,6)$, and it is a consequence of the lack of specificity of the final chromogen color reaction of this analytical procedure. Reducing substances either compete with the chromogen for $\mathrm{H}_{2} \mathrm{O}_{2}$ or keep it in reduced state leading to low glucose values (6). With regard to published data (1-6) and to our observation on the serum glucose depressing effect of Baralgin, the aim of this work was to investigate drugs, applied in the therapy of internal diseases, for their possible influence on serum glucose data, estimated with the GOD-Perid method. Simultane: ously the influence of drugs on serum urea data was investigated:

\section{Material and Methods}

The analyses were performed in clear, nonhemolyzed, fasting sera and in glucose water solutions before and after in vitro loading with each of the 50 drugs listed in table 1.

Most of the investigated drugs were in solution for intravenous application, except the oral tablet drugs Tolbusal, Meldian, Buformin, Daonil and Thyralette. The loading of sera and glucose solution $5.55 \mathrm{mmol} / 1(100 \mathrm{mg} / \mathrm{dl})$ was performed by dilution of the ampule contents with serum in the proportions found in $3000 \mathrm{ml}$ plasma $3 \mathrm{~min}$ after intravenous application, or by suspending 1 pulverized tablet in $3000 \mathrm{ml}$ serum.

Parallel analyses of glucose in unloaded and drug-loaded material were performed on the Autoanalyzer I Technicon with the GODPerid ABTS test ${ }^{1}$ ), where in the final colorimetric reaction the redox chromogen indicator ABTS (2,2'-Azino-di-(3-ethyl-benzthiazoline-6-sulphonic acid)) (7) is used. To investigate the eventual interference of 50 drugs (table 1) on urea results, analogous experiments in sera and urea solution $(0.83 \mathrm{mmol} / \mathrm{l}$; $50 \mathrm{mg} / \mathrm{dl}$ ) were performed. Urea was analyzed by the ureasehypochlorite procedure ${ }^{2}$ ).

1) Blood-Sugar GOD-Perid ABTS Biochemica Test Combination, Boehringer, Mannheim, Germany.

2) Urea Biochemica Test Combination, Boehringer, Mannheim, Germany. 
Tab. 1. List of investigated drugs.

\begin{tabular}{ll}
\hline Therapeutic & Proprietary Name \\
& (International Nonproprietary Name, \\
& INN)
\end{tabular}

\section{Cardiotonics: Ceditanid, Lekozid, Lanicor (INN* Lanatozid C, Lanatozid C, Digoxin)}

2. Antiarrhythmics: Gilurytmal (INN Ajmaline)

3. Vasoconstrictors: Adrenalin, Dihydroergotamin (INN Epinephrine, Dihydroergotamine mesilate)

\section{Antihypertonics: \\ 5. Anticoagulants: \\ 6. Diuretics: \\ 7. Antidiabetics:}

8. Antineoplastics:

\section{Sulfonamides: \\ 10. Antiemetics:}

11. Antihistaminics:

12. Vitamins:

13. Hormones:

14. Antibiotics:

15. Sedatives:

16. Anesthetics:

17. Hypnotics:

18. Spasmolytics:

19. Analgetics:
Serpasil (INN Reserpine)

Heparin (INN Heparin)

Lasix (INN Furosemide)

Insulin, Tolbusal, Meldian, Buformin, Daonil (INN Insulin, Tolbutamide, Chloropropamide, Buformin hydrochloride, Glibenclamide)

Antimit, Endoxan, Oncovin, Vinblastin, Daunoblastina (INN Chlormethine hydrochloride, Cyclophosphamide, Vincristine sulfate, Daunorubicin hydrochloride)

\section{Sulfazol (INN Sulfafurazol)}

Reglan (INN Metoclopramide)

Phenergan (INN Promethazine hydrochloride)

Plivit C, Plivit B1, Plivit B6, Plivit B12, Vitamin K1 (INN Ascorbic. acid., Thiamine hydrochloride, Pyridoxine hydrochloride, Cyancobalamin, Phytometadion)

Progesterone, Testosterone, Femandren M, Ultracorten, Thyralette (INN Progesterone, Testosterone, Estradiol benzoate - Testosterone isobutyrate, Prednisone, Levothyroxine sodium)

Ceporin, Penbritin, Streptomycin, Geomycin, Eritromicin, Garamycin, Kanamicin, Kemicetin, Vibramycin (INN Cefaloridine, Ampicillin, Streptomycin, Oxytetracycline, Erythromycin, Gentamycin sulfate, Kanamycin, Chloramphenicol, Doxycycline hyclate)

Apaurin (INN Diazepam)

Lidocain (INN Lidocaine)

Phenobarbitone (INN Phenobarbital)

Baralgin (INN Fenpiverinium bromideNoramidopyrinium methanesulfonate sodium-Pitofenone)

Butazolidin, Irgapyrin, Aminopyrin, Analgin, Novalgetol, Analgocain (INN Phenylbutażone, Aminophenazone Phenylbutazone, Aminophenazone, Noramidopyrinium methanesulfonate sodium, Noramidopyrinium methanesulfonate sodium, Noramidopyrinium methanesulfonate sodium - Lidocaine)

\section{Experiments and Results}

50 drugs were investigated. 7 drugs containing pyrazolone, pyrazolidine, phenazone or butazone and 2 drugs incorporating ascorbic acid (fig. 1, tab. 2) caused a de-

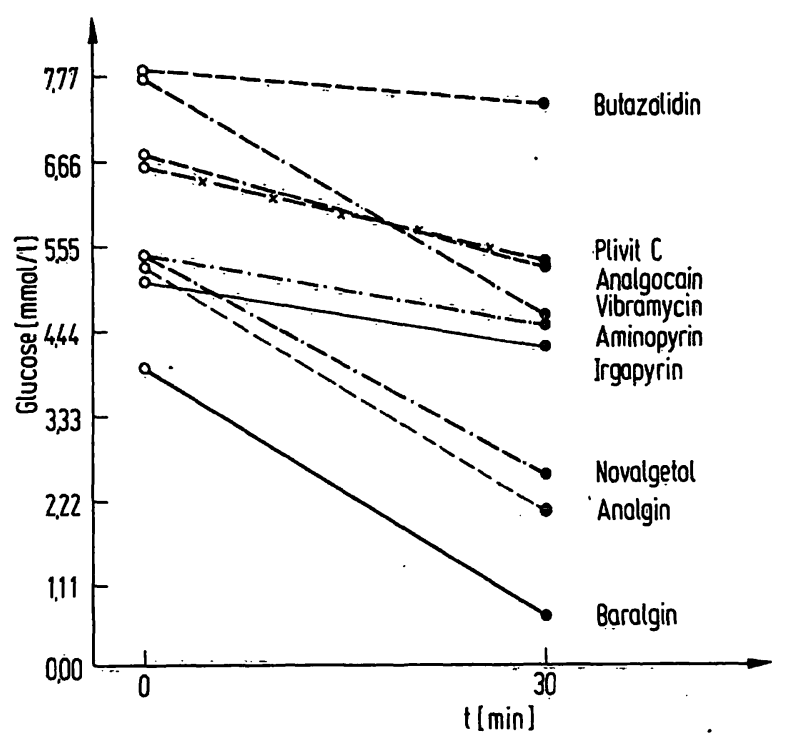

Fig. 1. Influence of 9 investigated drugs interfering with serum glucose data. o Sera, $\bullet$ Loaded sera.

For INN see tables 1, 2.

Tab. 2. Drugs interfering with serum glucose values.

\begin{tabular}{|c|c|c|}
\hline Drug & Formula & $\begin{array}{l}\text { Inter- } \\
\text { ference }\end{array}$ \\
\hline $\begin{array}{l}\text { 1. Plivit C amp. } \\
\text { "Pliva" }\end{array}$ & $500 \mathrm{mg}$ sodium ascorbate & + \\
\hline $\begin{array}{l}\text { 2. Vibramycin amp. } \\
\text { "Pfizer" }\end{array}$ & $\begin{array}{l}100 \mathrm{mg} \cdot d o x i c y c l i n \\
480 \mathrm{mg} \text { ascorbic acid }\end{array}$ & + \\
\hline 3. Baralgin amp. & $\begin{array}{l}2500 \text { mg sodium-phenyl- } \\
\text { dimethyl-pyrazolon-methyl- } \\
\text { aminomethan-sulphonate + } \\
10 \text { mg p-piperidinoethoxy- } \\
\text { o-carbmethoxy-benzophenon- } \\
\text { hydrochloride }+0.10 \mathrm{mg} \\
\text { diphenylpiperidinoethyl- } \\
\text { acetamid-brom-methylatum }\end{array}$ & + \\
\hline $\begin{array}{l}\text { 4. Butaziolidin amp. } \\
\text { (Phenylbutazon) } \\
\text { "Geigy" }\end{array}$ & $\begin{array}{l}600 \mathrm{mg} 1,2 \text { diphenyl-3,5- } \\
\text { dioxo-4-N butyl pyrazolidin } \\
\text { sodium (phenylbutazon } \\
\text { sodium) }+30 \mathrm{mg} \text { diethyl- } \\
\text { aminoacet- } 2,6-0 \text {-xylidid }\end{array}$ & + \\
\hline $\begin{array}{l}\text { 5. Analgin amp. } \\
\text { "Pliva" }\end{array}$ & $\begin{array}{l}2500 \text { mg nor-amino- } \\
\text { phenazonemesilas sodium }\end{array}$ & + \\
\hline $\begin{array}{l}\text { 6. Novalgetol amp. } \\
\text { "Galenika" }\end{array}$ & $\begin{array}{l}2500 \text { mg sodium } 1 \text { phenyl- } \\
2,3-\text { dimethyl-3-pyrazolin-5 } \\
\text { on-4-methyl-aminomethansul- } \\
\text { phonate }\end{array}$ & + \\
\hline $\begin{array}{l}\text { 7. Analgocain amp. } \\
\text { "Galenika" }\end{array}$ & $\begin{array}{l}2500 \text { mg nor-aminophenazone } \\
\text { mesilas sodium }+25 \mathrm{mg} \text { lido- } \\
\text { cain hydrochloride }\end{array}$ & + \\
\hline 8. Irgapyrin amp. & $\begin{array}{l}450 \mathrm{mg} 1-2 \text { diphenyl-3,5 } \\
\text { dioxo-4-N buthyl pyrazolidin } \\
\text { sodium }+450 \mathrm{mg} \text { l-phenyl- } \\
\text { 2,3-dimethyl-4-dimethylamino- } \\
\text { pyrazolon }+30 \mathrm{mg} \text { diethyl- } \\
\text { aminoacet-2-0-xylidid }\end{array}$ & + \\
\hline 9. Aminopyrin tbl. & $300 \mathrm{mg}$ aminophenazone & + \\
\hline
\end{tabular}

*) World Health Organization

International monitoring of adverse reactions to drugs

Drug Reference List No 13, 1975.

Suppl. No 1, 2, 3 Ref. No 271, 279, 287, 1976. 
crease in the measured value for serum glucose. Since Baralgin showed the greatest effect (fig. 1), further experiments were performed with $85 \mathrm{mg}$ Baralgin per $100 \mathrm{ml}$ of serum or glucose solution. Statistical evaluation of 32 serum glucose data before $(\bar{x} \pm s=4.94 \pm$ $1.17 \mathrm{mmol} / \mathrm{l})$ and $30 \mathrm{~min}$ after loading $(\overline{\mathrm{x}} \pm \mathrm{s}=0.79 \pm$ $0.62 \mathrm{mmol} / \mathrm{l})$ demonstrated a statistically significant glucose depressing effect of Baralgin of $(P<0.001)$. The difference between mean glucose values in unloaded and Baralgin-loaded sera was $4.15 \mathrm{mmol} / \mathrm{l}$ glucose.

The difference between mean glucose data for glucose solutions of $5.55,11.11,16.65$, and $22.22 \mathrm{mmol} / 1$ before and after Baralgin-loading was found to be $2.89 \mathrm{mmol} / 1$.

The addition of $10,20,30,40,50,60,70,80,90$, and $100 \mathrm{mg}$ of Baralgin to $100 \mathrm{ml}$ serum or glucose solution $(5.55 \mathrm{mmol} / \mathrm{l})$ showed a direct relationship., between the Baralgin concentration and its depressing influence on the glucose data. Glucose values were determined in 10 different sera $(\bar{x}=4.03 \mathrm{mmol} / \mathrm{l})$ immediately, and 30,60, and 120 min after loading with Baralgin. The glucose data were most depressed immediately after drug addition $(\overline{\mathrm{x}}=1.58 \mathrm{mmol} / \mathrm{l})$; after 30 , 60 , and $120 \mathrm{~min}$ the decrease was $0.58,0.33$ and $0.27 \mathrm{mmol} / 1$ glucose, respectively. None of the $50 \mathrm{in}$ vestigated drugs affected the urea values in serum or urea solution.

\section{Discussion}

In this work it was showed that 7 drugs, containing pyrazolone or derivates lead to a decrease in the reported value for serum glucose, investigated with the GOD-Perid ABTS method. These drugs contain the hydrazine-N-N-group, which might have an acceptor function for the oxygen (5) derived from $\mathrm{H}_{2} \mathrm{O}_{2}$ in the GOD-Perid ABTS analytic procedure, and possibly inhibit the chromogen ABTS reaction. The effect depends upon the drug concentration in the serum, the time interval between drug-loading and glucose analysis, and probably on the type of substituent in the pyrazolone. These findings are in accordance with published data on the glucose depressing effect of drugs with a hydrazine group in close proximity to benzene nucleus (5). Some drugs might compete with the chromogen for $\mathrm{H}_{2} \mathrm{O}_{2}$ or keep it in reduced state, leading to GOD-POD reactions that are not specific for the glucose determination (6).

Our findings show that some unpublished pyrazolone drugs, depress GOD-Perid serum glucose values, and complete the list of other drugs with a similar effect described earlier (1-6). The interaction of ascorbic acid, in amounts greater than $16.6 \mathrm{mg}$ in $100 \mathrm{ml}$ serum, with glucose data is confirmed in this work, although no interference by amounts less than $5.0 \mathrm{mg}$ ascorbic acid in $100 \mathrm{ml}$ sera was observed earlier (9).

\section{References}

1. Caraway, W. T. (1965), Am. J. Clin. Pathol. 37, 445-464.

2. Sharp, P. (1972), Clin. Chim. Acta 40, 115-120.

3. Wirth, W. A. \& Thompson, R. L. (1965), Am. J. Clin. Pathol. 43, 579-590.

4. Elking, M. P. \& Kabat, H. F. (1968), Am. J. Hosp. Pharm. 25, 485-519.

5. Sharp, P., Reley, C., Cook, J. G. H. \& Pink, P. J. F. (1972), Clin. Chim. Acta 36, 93-98.

6. Caraway, W. T. \& Kammeyer, C. W. (1972), Clin. Chim. Acta 41, 395-434.

7. Werner, W., Rey, H. G. \& Wiehlinger, H. (1970), Z. Anal. Chem. 252, 224-228.

8. Fawcett, J. K. \& Scott, J. E. (1960), J. Clin. Pathol. 13, 156-159.

9. Keler-Bačoka, M., Stojanovski-Bubanj, A. \& Blažević, K. (1971), Farm. glas. 27, 367-370.

\author{
Prof. Dr. Mira Keler-Bačoka, \\ Institute of Medical Biochemistry, \\ Clinic for Internal Diseases, \\ Medical Faculty, \\ University of Zagreb, \\ Zagreb, Rebro, \\ Yugoslavia
}


